\title{
PENINGKATAN KEMAMPUAN BERTANYA DAN PENGUASAAN KONSEP IPA MELALUI PENDEKATAN QUESTION FORMULATION TECHNIQUE (QFT)
}

\author{
INCREASING QUESTIONING SKILL AND SCIENCE CONCEPTUAL \\ COMPREHENSION THROUGH THE USE OF QUESTION FORMULATION \\ TECHNIQUE
}

\author{
Fitria Agustini, Wahyu Sopandi \\ Guru Sekolah Dasar Negeri 089 Babakan Ciparay Bandung \\ E-mail: fitriakupiet@yahoo.com
}

\begin{abstract}
ABSTRAK
Penelitian ini bertujuan untuk mengetahui peningkatan kemampuan bertanya dan penguasaan konsep IPA melalui pendekatan Question Formulation Technique (QFT). Metode penelitian yang digunakan pada penelitiian ini adalah kuasi eksperimen dengan model matching only pretest posttest. Subjek Penelitian ini terdiri dari 62 siswa kelas IV Sekolah dasar yang terdiri dari 32 siswa kelas eksperimen dan 30 siswa kelas kontrol. Instrumen penelitian yang digunakan yaitu tabel observasi untuk mengetahui banyak pertanyaan yang dibuat siswa dan pretest posttes untuk penguasaan konsep. Hasil penelitian ini menunjukkan bahwa siswa yang pembelajarannya menggunakan QFT mampu membuat pertanyaan yang jumlah lebih banyak dibanding siswa kelas kontrol. Tipe pertanyaaan yang banyak dibuat siswa adalah tipe pertanyaan mengumpulkan informasi Faktual. selain itu juga siswa yang pembelajarannya menggunakan Pendekatan QFT menunjukkan peningkatan yang sangat signifikan dimana rerata $\mathrm{N}-$ Gain penguasaan konsep pada kelas eksperimen sebesar 0,435.
\end{abstract}

Kata Kunci: bertanya, penguasaan konsep, Pendekatan QFT

ABSTRACT

This study aims at understanding how Question formulation Technique can increase student's questioning and conceptual understanding, The method used in this study was quasi experiment with matching only pretest posttest model. Subject of this study were 62 students in grade fourth primary school consisting of 32 students experimental group and 30 students control group. The research instrument used in this study were observation table to observe student questioning form, and pretest posttes for measure concept understanding. This study indicated that students lwho were learning through question formulation technique was able to create more questions than students in control group. Type of question that student created was in the form of gathering factual information. Other than that the student who learnd by question formulation technique showed significance concept understanding which was proven by its $N$-gain $(0,435)$.

Keyword: asking question, concept understanding, Question Formulation Technique

\section{PENDAHULUAN}

Pendidikan adalah usaha sadar dan terencana untuk mewujudkan suasana belajar dan proses pembelajaran agar peserta didik secara aktif mengembangkan potensi dirinya untuk memiliki kekuatan spiritual keagamaan, pengendalian diri, kepribadian, kecerdasan, akhlak mulia, serta keterampilan yang diperlukan dirinya, masyarakat, bangsa dan negara (Depdiknas, UU No. 20 Tahun 2003, Bab 1, Pasal 1). Berdasarkan hal tersebut bahwa sebuah pendidikan yang benar yaitu suatu proses yang direncanakan untuk membentuk siswa yang tidak hanya cakap dalam pengetahuan dalam ilmu tertentu tetapi memiliki sikap dan keterampilan yang berguna bagi mereka dalam menjalani kehidupannya.

Proses pendidikan yang diharapkan dijabarkan pada Badan Standar Nasional Pendidikan, Peraturan Pemerintah Nomor 19 Tahun 2005 tentang Standar Nasional Pendidikan, Pasal 19 ayat (1) tentang standar proses, dinyatakan bahwa: Proses pembelajaran pada satuan Pendidikan diselenggarakan secara interaktif, inspiratif, menyenangkan, menantang, memotivasi peserta didik untuk berpartisipasi aktif serta memberikan ruang yang cukup bagi prakarsa, kreativitas dan kemandirian sesuai 
dengan bakat, minat, dan perkembangan fisik serta psikologis peserta didik. Hal tersebut di atas diperjelas lagi dalam Badan Standar Nasional Pendidikan, Permendiknas No. 22 Tahun 2006 tentang standar isi dinyatakan bahwa pembelajaran IPA sebaiknya dilaksanakan secara inkuiri ilmiah (scientific inquiry) untuk menumbuhkan kemampuan berpikir, bekerja dan bersikap ilmiah serta mengkomunikasikannya sebagai aspek penting kecakapan hidup.

Menilik hal-hal tersebut di atas maka disimpulkan bahwa sebuah proses pembelajaran yang harus terjadi di dalam kelas yaitu kegiatan pembelajaran yang dapat memotivasi siswa untuk bisa berpartisipasi aktif dalam proses tersebut dengan kata lain siswa yang akan mendominasi sebuah kegiatan pembelajaran dalam kelas dan guru berperan sebagai fasilitator dalam kegiatan tersebut. Dalam menciptakan kegiatan pembelajaran yang seperti itu tentu saja guru harus memiliki sebuah strategi yang baik agar dapat membangun rasa ingin tahu siswasehingga siswa memiliki minat yang tinggi untuk melakukan eksplorasi dan investigasi dalam mendapatkan ilmu pengetahuan.

Guru dalam membangun iklim kelas yang baik harus tahu betul bagaimana pembelajaran yang akan disampaikan harus sesuai dengan tujuan dan makna dari pelajaran tersebut. Hal ini dikarenakan setiap mata pelajaran memiliki karakteristik tertentu seperti halnya pembelajaran Ilmu Pengetahuan Alam (IPA) dimana dalam kegiatan pembelajarannya harus sesuai dengan hakikat sains. IPA di sekolah dasar bukan hanya sekedar hafalan. Anak harus diberikan kesempatan untuk mengembangkan sikap ingin tahu dan berbagai penjelasan logis. Hal ini akan mendorong anak untuk mengekspresikan kreatifitasnya. Pembelajaran IPA memberikan kesempatan kepada siswa untuk melakukan berbagai penguatan dan latihan-latihan yang berkaitan dengan cara berpikir sehat, alamiah dan masuk akal dalam kehidupan sehari-hari. Menurut Sriarunrasmee \& Suwannatthachote (2015:1722), Ketika merancang pembelajaran sains, guru harus bisa menciptakan pembelajaran yang dapat meningkatkan keterampilan dan proses sains. keterampilan proses sains ini berguna sebagai pondasi atau alat untuk meningkatkan kemampuan berpikir dan menyelesaikan masalah.

Hal ini diperkuat oleh hasil PISA tahun 2012 dimana negara kita berada pada peringkat 64 dari 65 negara yang mengikuti survei tersebut, peringkat yang diperoleh ini menunjukkan bahwa pendidikan yang ada di Indonesia masih buruk. Prestasi yang buruk ini disebabkan oleh banyak faktor salah satunya dimungkingkan temuan Depdiknas tahun 2008 masih tetap terjadi sampai saat ini dimana pembelajaran IPA yang terjadi dilapangan masih belum mampu untuk mengembangkan kemampuan siswa secara maksimal karena kegiatan pembelajaran yang ada masih cenderung berpusat pada guru. Pembelajaran yang seperti itu menyebabkan siswa di kelas bersikap pasif karena hanya menerima informasi dari guru dan mengakibatkan siswa memiliki daya ingat yang sementara dalam artian mereka hanya mengingat penjelasan guru saat pembelajaran berlangsung.

Padahal jika dilihat dari esensi UU No. 20 Tahun 2003 dan Peraturan Pemerintan No. 19 Tahun 2015 bahwa pembelajaran yang baik adalah pembelajaran yang melibatkan siswa aktif dalam setiap pembelajaran, salah satu tolak ukur siswa aktif dalam pembelajaran yang sesuai dengan pembelajaran IPA yang mengarah pada pembelajaran yang bersifat inkuiri. NRC dalam Şimşek \& Kabapınar (2014:1193) mendefinisikan inkuiri sebagai rangkaian proses yang saling berkaitan dimana peneliti atau siswa membuat pertanyaan mengenai fenomena alam dan menyelidikinya. Pada kegiatan tersebut siswa akan memperoleh pengetahuan dan meningkatkan pemahaman konsep. Lippman pada Siew \& Abdullah (2013:100) 
menyatakan anak-anak sebagai peserta didik aktif secara alami memiliki sifat ingin selalu bertanya, dan memiliki rasa ingin tahu yang besar. Selain itu juga bertanya menjadi alat ukur dalam berpikir karena dengan siswa bertanya dapat membantu untuk menciptakan ide dan meningkatkan pemahaman siswa terhadap konsep-konsep IPA dan fenomenanya. Tindakan mengajukan pertanyaan dan pencarian jawaban adalah kunci untuk belajar aktif (Musingafi \& Muranda, 2014:106).

Menurut Cardoso \& Almeida (2014:3776) proses tanya jawab membantu siswa dalam pembelajaran dimana siswa akan menyatukan pengetahuan sebelumnya dengan informasi yang mereka dapat sehingga membentuk ide atau pemahaman baru bagi mereka. pertanyaan siswa memiliki peranan yang sangat penting dalam pembelajaran bermakna dan memotivasi siswa. Pertanyaan siswa juga dapat menggambarkan sejauh mana kualitas berpikir siswa dan tingkat pemahaman siswa. Patrícia Albergaria Almeida (2013:635) mengemukakan bahwa mengajukan pertanyaan merupakan elemen kunci dalam proses pembelajaran. Tanya jawab membantu siswa mengarahkan pembelajaran mereka karena mereka mencoba untuk menggabungkan pengetahuan dan informasi baru dalam upaya mereka untuk memahami ide-ide. Pertanyaan siswa memainkan peran penting dalam pembelajaran bermakna, dan dapat menunjukkan kualitas siswa dalam berpikir dan pemahaman konsep.

Selajutnya menurut Davis pada Etemadzadeh, Seifi, \& Far (2013:1026) dengan melakukan teknik tanya jawab dikelas akan membantu: 1) Pembelajaran yang aktif dan pembelajaran yang berpusat pada siswa, 2) membantu siswa untuk mengkontruksi pengetahuannya, 3) membantu siswa untuk meningkatkan kemampuan untuk menyelesaiakan masalah, 4) Meningkatkan pemahaman dalam jangka panjang. Berdasarkan pendapat tersebut di atas maka dapat disimpulkan betapa pentingnya melatih siswa untuk bertanya karena dengan melatih siswa bertanya akan membentuk siswa yang memiliki pemikiran yang kritis dan selain itu juga memotivasi siswa untun belajar mandiri serta membantu siswa untuk menemukan ide dan pemahamannya dalam ilmu pengetahuan. Pertanyaan dapat diklasifikasikan berdasarkan pertimbangan tertentu. Istilah pertanyaan tidak selalu dalam bentuk kalimat tanya tetapi dapat juga dalam bentuk pernyataan, asalkan keduanya menginginkan tanggapan verbal (Kemdikbud, 2014:67). Berkowitz dalam Farmer (2014:43) menyatakan pertanyaan yang ideal adalah pertanyaan yang melibatkan pencarian informasi secara intelektual dan menyebabkan mereke untuk berpikir.

Telah banyak penelitian yang menganalisi kemampuan bertanya siswa, diantara penelitian yang dilakukan oleh Widodo(2012) mengenai keterampilan bertanya, yaitu: 1) kurangnya keterampilan bertanya siswa dalam bertanya pada diri siswa menyebabkan suasana kelas kurang aktif selama pembelajaran berlangsung; 2) penyebabnya kurangnya keaktifan dan keterampilan siswa dalam bertanya akibat tidak adanya keberanian siswa dalam bertanya. Hal ini disebabkan adanya perasaan takut jika pertanyaan yang diungkapkan melenceng dari materi yang dijelaskan; 3) Keterampilan siswa dalam bertanya dapat meningkatkan kemampuan berpikir secara sistematis, dan memperluas wawasan siswa terutama berhubungan dengan praktif kehidupan di dalam masyarakat; 4) keterampilan siswa dalam bertanya dibutuhkan siswa dalam melaksanakan proses pembelajaran sehingga akan berdampak pada ke dalaman materi yang diterima sekaligus meningkatkan prestasi belajar siswa.

Vianata (2012) yang mengemukakan faktor yang menyebabkan siswa tidak aktif bertanya adalah siswa yang kurang berani untuk bertanya padahal dalam dirinya sudah ada pertanyaan yang akan disampaikan. Sedangkan menurut penelitian mengenai 
faktor penyebab kesulitan siswa dalam mengungkapkan pertanyaan dilakukan oleh Cholifah, Hendri, \& Deswati (2013) didapati bahwa kesulitan siswa dalam mengungkapkan pertanyaan di kelas termasuk ke dalam kategori kesulitan yang tinggi salah satunya adalah indikator hubungan siswa dengan guru memiliki presentase sebesar $61,66 \%$. Pada penelitian tersebut membuktikan siswa kurang dapat berkomunikasi dengan guru sehingga muncul perasaan takut dan enggan kepada guru. hal ini menyebabkan kesulitan siswa bertanya di dalam kelas, padahal pertanyaan merupakan salah satu unsur yang cukup penting dalam proses pembelajaran.

Widodo (2012) mengungkapkan bahwa siswa sangat sedikit mengajukan pertanyaan secara lisan, namun setelah diberi kesempatan untuk menuliskan pertanyaan-pertanyaan mereka, ternyata siswa bisa memunculkan banyak sekali pertanyaan. Berdasarkan penyataan tersebut menunjukkan bahwa siswa kurang mendapatkan latihan untuk mengajukan pertanyaan. Kebiasaan siswa yang kurang terlatih dalam mengajukan pertanyaan dapat dikarenakan guru berbalik memberikan pertanyaan kepada siswa atau seringkali guru lebih memberikan reinforcement positif jika siswa menjawab pertanyaan tetapi kurang memberikan reinforment positif jika siswa mengajukan pertanyaan karena pola pikir yang terbentuk pertanyaan yang ditanyakan siswa karena siswa tidak mengerti materi yang sedang dipelajari bukan karena siswa memiliki rasa ingin tahu yang besar untuk lebih jauh mendapatkan informasi sehingga menjadikan siswa menjadi kurang percaya diri dan memilih untuk diam.

Untuk mengatasi masalah itu terdapat sebuah pendekatan yang dinamakan The Right Question Institute, merupakan sebuah pendekatan yang membantu siswa untuk membuat pertanyaannya sendiri yaang dinamakan Question Formulation Technique(QFT). Pada penelitian yang dilakukan oleh RQI ini menunjukan bahwa
QFT mem-brainstroming siswa menjadi merasa lebih tertantang mengembangkan percobaan sains, menciptakan penelitian sendiri, terbiasa menulis essay, dan terbiasa untuk mengkomunikasikan. Dimana Pendekatan QFT ini memiliki 6 tahapan, diantaranya: (1) A Question Focus (Qfocus), (2) The rules for producing question, and Producing question, (3) Categorizing Question, (4) Prioritizing Question, (5) Next steps, (6) Reflection.

QFT didesain tahapan demi tahapan untuk memfasilitasi siswa untuk membuat banyak pertanyaan tetapi tidak hanya itu saja dengan membuat pertanyaan akan melatih siswa untuk berpikir lebih dalam dari pertanyaan yang mereka buat. siswa yang melakukan tahapan-tahapan QFT, selain mereka dapat membuat pertanyaan mereka juga akan terlatih untuk berpikir secara divergen, convergen, dan metakognitif. Elves (2013) menyatakan bahwa saat siswa diperkenalkan pada Teknik QFT ini menunjukkan respon yang positif dimana siswa yang ditelitinya memiliki motivasi yang tinggi untuk membuat pertanyaan-pertanyaan. Maka berangkat dari hasil penelitian tersebut peneliti memiliki asumsi jika teknik QFT ini dapat membantu siswa agar terbiasa untuk membuat pertanyaan sendiri yang tentunya akan berguna bagi siswa salah satunya dalam meningkatkan penguasaan konsep IPA.

\section{METODE PENELITIAN}

Metode yang digunakan dalam penelitian ini adalah metode kuasi eksperimen. Pelaksanaan pembelajaran dengan menggunakan pendekatan QFT kemudian dilihat pengaruhnya terhadap peningkatan kemampuan bertanya dan penguasaan konsep IPA siswa. Desain penelitian yang dipilih yaitu "Matching Only Pretest Posttest Control Group Design". Desain ini melibatkan dua kelompok sampel, yaitu kelompok eksperimen dan kelompok kontrol yang dipilih tanpa melalui random sampling. Variabel Bebas: Pendekatan Pembelajaran, 
dimana kelas eksperimen menggunakan Pendekatan Question Formulation Technique (QFT), dan kelas kontrol menggunakan pembelajaran konvension. Variabel Terikat: Peningkatan kemampuan bertanya dan penguasaan konsep IPA siswa. Variabel Kontrol: Motivasi siswa, gaya belajar, kondisi kelas, dll.

Penguasaan konsep IPA pada kedua kelompok diukur dua kali, yaitu pada saat pre-test dan post-test. Sedangkan pada peningkatan kemampuan bertanya siswa, pengukuran dilakukan pada saat sebelum eksperimen dan setiap pembelajaran berlangsung. Pre-test dilakukan untuk mengetahui keadaan awal apakah terdapat perbedaan antara kedua kelompok. Hasil pre-test yang diharapkan adalah tidak adanya perbedaan tingkat penguasaan konsep IPA maupun kemampuan bertanya siswa yang signifikan antara kelompok eksperimen maupun kelompok kontrol. Pretest dan post-test terhadap kedua kelompok dilakukan menggunakan isntrumen yang sama Fraenkel \& Wallen (2013:276-278). Hasil post-test kedua kelompok selanjutnya dibandingkan untuk membuktikan adanya penbedaan tingkat penguasaan konsep IPA dan Kemampuan bertanya siswa

Populasi yang dipilih adalah seluruh siswa kelas di salah satu sekolah dasar yang tersebar di empat kelas sebanyak 120 orang siswa. Selanjutnya dipilih 32 siswa untuk dijadikankan kelas eksperimen dan 30 siswa sebagai anggota kelas kontrol. Kedua kelas ini dipilih karena dianggap mewakili populasi dengan karakteristik yang sama ditinjau dari tingkat usia, tempat tinggal, serta latar belakang. Instrumen penelitian yang digunakan dalam penelitian terdiri atas.

1. Soal tes penguasaan konsep IPA

Instrumen tes dirancang dalam bentuk soal pilihan ganda. Perangkat soal digunakan untuk memperoleh data prestest dan posttest pada kedua kelompok sampel dengan pokok bahasan Perubahan Kenampakan Bumi dan Benda Langit menyajikan penyebaran penguasaan konsep C1-C4 dalam soal yang telah di uji validasi, reliabilitas, tingkat kesukaran serta daya pembedanya.

2. Tabel observasi

Mengukur tingkat peningkatan kemampuan bertanya yang dibuat siswa berdasarkan tingkatan Measure of Questioning Skills (MSQ). Observasi peningkatan kemampuan bertanya siswa dilakukan pada setiap pertemuan dengan mengobservasi pertanyaan yang ditulis siswa dan mengelompokkannya sesuai dengan MSQ.

\section{HASIL DAN PEMBAHASAN}

Sesuai dengan metodelogi yang digunakan dalam penelitian ini diuraikan hasil pengolahan dan analisis terhadap data-data yang terkumpul dalam penelitian untuk selanjutnya dijadikan bahan untuk melakukan pembahasan. Data berupa angka terdiri dari data jumlah banyaknya pertanyaan yang dibuat siswa, dan skor pretest dan posttest penguasaan konsep. Kedua data tersebut di olah secara kuantitatif dimana data untuk kemampuan bertanya dihitung dengan program Microsoft Excel, dan untuk data penguasaan konsep dihitung dengan menggunakan SPSS Versi 2I, sedangkan data dalam lembar observasi kegiatan pembelajaran dan angket siswa digunakan sebagai respon bagaimana pembelajaran menggunakan Pendekatan Question Formulation Technique (QFT).

Berikut disajikan gambaran kemampuan bertanya siswa, baik pada kelompok eksperimen maupun kelas kontrol. Kemampuan bertanya diukur dengan tiga indikator yakni mengumpulkan informasi (faktual dan prosedural), mengorganisir infomasi (objektif dan asumsi) dan memperluas informasi (hipotesis dan spekulasi). Sedangkan pengukuran kemampuan bertanya menggunakan pendekatan jumlah pertanyaan yang diajukan dan jumlah siswa yang bertanya (jumlah penanya). 

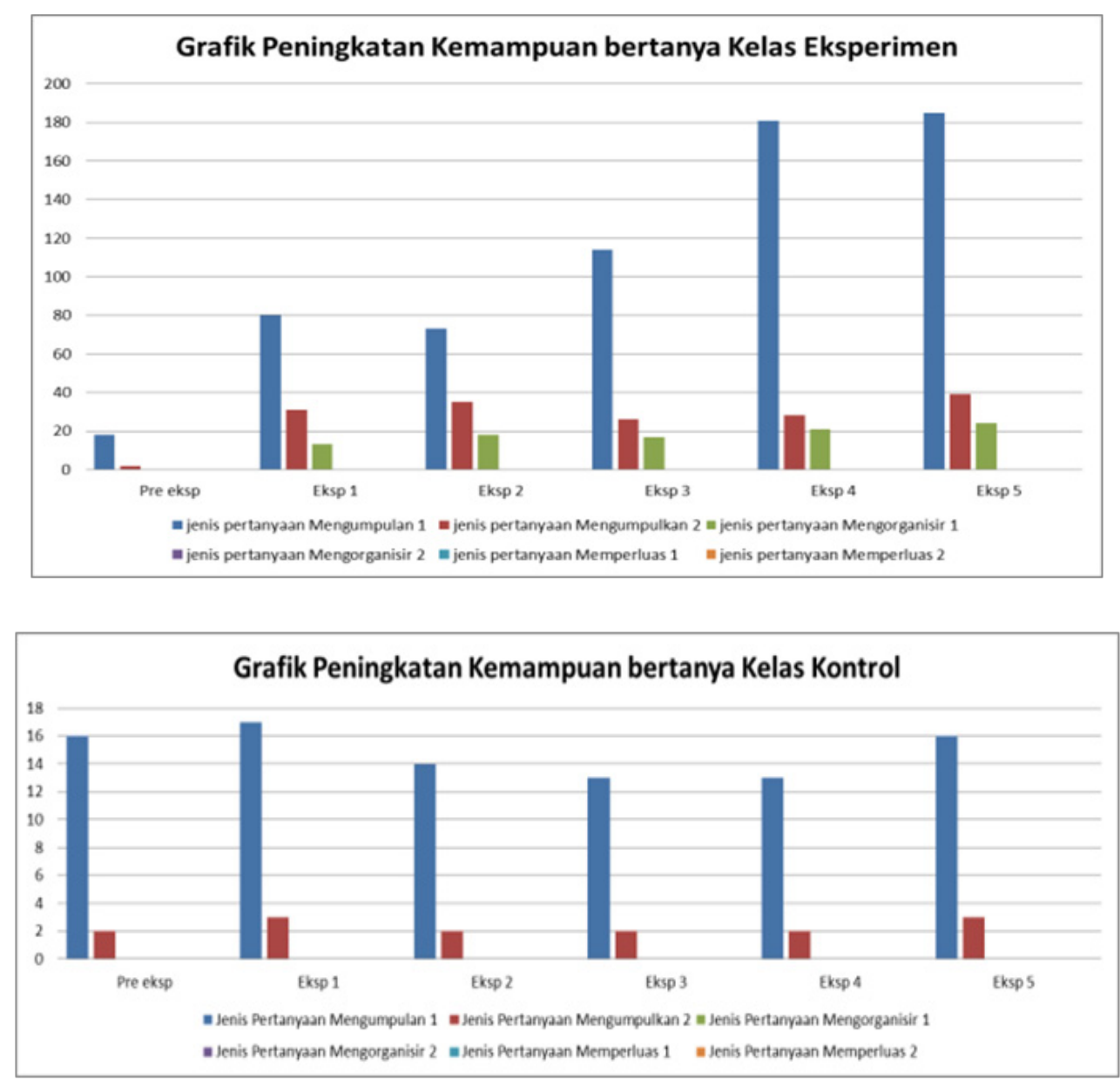

Jika dilihat dari grafik di atas, peningkatan jumlah pertanyaan menunjukkan peningkatan yang sangat signifikan, dimana pada saat Preeksperimen dilakukan siswa hanya mampu membuat pertanyaan pada kategori mengumpulkan informasi faktual 18 buah dan mengumpulkan informasi prosedural sebanyak 2 buah. hal ini bisa disebabkan oleh beberapa hal salah satunya karena pengetahuan awal yang dimiliki siswa kurang dan siswa tidak tahu apa yang harus ditanyakan kepada guru karena mereka tidak fokus atau tidak tahu materi yang perlu ditanyakan. Hal ini senada dengan pendapat Patrícia Albergaria Almeida (2013:241-242) ada beberapa alasan mengapa siswa tidak mau mengajukan pertanyaan adalah, 1) tidak bisa mendeteksi cognitive disequilibrium, 2) bisa mendeteksi cognitive disequilibrium tetapi tidak mau mengakui bahwa dirinya kurang paham, 3) tidak bisa bertanya langsung, 4) bisa bertanya tetapi memilih bertanya kepada siswa dari pada guru.
Tetapi saat dilakukan perlakuan yaitu pada eksperimen pertama sampai kelima jumlah pertanyaan yang dihasilkan siswa semakin meningkat terutama pada kategori mengumpulkan informasi faktual, sedangkan pada mengumpulkan informasi prosedural dan mengorganisir informasi objektif peningkatan yang terjadi kurang signifikan. Dan selain itu tidak munculnya pertanyaan pada kategor mengorganisir pertanyaaan asumsi, memperluas informasi hipotesis dan spekulasi.

Peningkatan yang signifikan pada jumlah pertanyaan pada salah satu kategori penulis mengasumsikan bahwa dengan adanya perlakuan dengan menggunakan pendekatan QFT ternyata dapat meningkatkan produksi pertanyaan meskipun masih pada tahapan pertanyaan yang bersifat Low Order Thinking Skill (LOTS). Bentuk Pertanyaan yang dibuat siswa bergantung pada berbagai hal di antaranya menurut Scardamalia dan Bereiter, pada Hung, Hwang, Lee, Wu, 
\& Vogel (2014:318) menyatakan bahwa kurangnya pengetahuan siswa sebelumnya dapat mempengaruhi pertanyaan yang dibuat oleh siswa tersebut. Berdasarkan pendapat tersebut maka kemungkinan besar siswa belum bisa membuat pertanyaan pada level High Order Thinking Skill (HOTS) hal ini dikarenakan pengetahuan awal siswa kurang mumpuni. Selain alasan di atas ada berbagai alasan lain yang menyebabkan siswa kurang mampu membuat pertanyaan yang sifat HOTS dimungkinkan karena strategi yang diberikan dalam hal ini Qfocus yang dbuat guru kurang mampu meningkatkan pemikiran siswa.

Sebagaimana penelitian yang dilakukan Cardoso \&Almeid,(2014:3783-3784) dimana mereka menggunakan tiga strategi untuk meningkatkan anak mengajukan pertanyaan strategi pertama dengan penonton video, kedua melakukan perkerjaan laboratorium, dan ketiga dengan membaca teks. dari ketiga strategi tersebut strategi pertama menunjukkan bahwa siswa lebih banyak membuat pertanyaan pada level informasi (apa, dimana,yang mana) dan pemahaman (mengapa ?, bagaimana?) dan sangat sedikit pada level menemukan solusi (bagaimana jika?,jika ... maka ?). tetapi pada stategi ketiga dimana siswa membaca teks menunjukkan bahwa siswa membuat pertanyaan pada level pemahaman dan menemukan solusilah yang paling tinggi.

Hasil penelitian tesebut diatas menjawab mengapa siswa kurang mampu membuat pertanyaan pada kategori memperluar informasi secara hipotesis dan secara spekulasi karena pada penelitian ini Qfocus yang digunakan pada penelitian ini berupa gambar, dan video. Merujuk pada penelitian Cardoso \& Almeida (2014) siswa yang mendapat perlakuan untuk membaca teks, mereka mampu memproduksi pertanyaan pada level HOTS, maka ini berarti bahwa pertanyaan yang dibuat sangat bergantung pada pengetahuan awal siswa. Pada kelas kontrol peningkatan jumlah siswa yang bertanya tidak menunjukkan peningkatan yang signifikan padaindikatormengumpulkan informasi (faktual dan prosedural), dan untuk indikator mengorganisir infomasi (objektif dan asumsi) dan memperluas informasi (hipotesis dan spekulasi) tidak ada satupun siswa yang mengajukan pertanyaan sejak pengukuran awal hingga pengukuran akhir. Hal ini dimungkinkan karena siswa yang berada pada kelas kontrol tidak mendapatkan perlakuan yang sama dengan kelas eksperimen dimana kelas eksperimen diberikan perlakuan yaitu berupa pendekatan QFT, hal ini didukung oleh data empiris ini didukung penelitian yang dilakukan oleh Elves (2013) dimana beliau melakukan sebuah action research yang menunjukkan hasil bahwa dengan menggunakan pendekatan $Q F T$ dapat memancing dan meningkatkan rasa penasaran siswa untuk membuat pertanyaan dengan diawali Qfocus.

Qfocus itu sendiri ada sebuah tema yang diangkat oleh guru agar siswa bisa membuat pertanyaan yang terpusat pada sebuah tema. Qfocus itu sendiri bisa berbentuk sebuah penyataan, gambar, dan video. Pada penelitian ini Qfocus yang digunakan pada kelas eksperimen merupakan video dimana pada pertemuan kesatu sampai ketiga mengenai konsep kenampakan bumi dan perubahan kenampakan bumi dampak yang ditimbulkan dari perubahan kenampakan bumi dan pada pertemuan keempat-kelima benda-benda langit posisi bulan dan kenampakan bumi dari hari kehari. Untuk mengetahui perbedaan peningkatan kemampuan penguasaan konsep IPA siswa antara kelas eksperimen dan kontrol, maka dapat dilihat pada rata-rata nilai $\mathrm{N}$-gain setiap kelompok

Hal ini menunjukkan adanya hubungan siswa kelas eksperimen yang mendapat perlakuan untuk membuat pentanyaanpertanyaan dengan pendekatan QFT menunjukkan hubungan yang positif karena dengan siswa membuat pertanyaanpertanyaan siswa dapat memprediksi sejauh mana kemampuannya dalam memahami materi. Hal ini senada dengan penelitian 
Tabel

Nilai N-Gain Kelompok Eksperimen dan Kontrol

\begin{tabular}{lccc}
\hline \multicolumn{1}{c}{ Kelas } & Jumlah Siswa & Rata-rata Nilai N-gain & Kriteria \\
\hline Eksperimen & 32 & 0,435 & Sedang \\
\hline Kontrol & 30 & $-0,014$ & Rendah \\
\hline
\end{tabular}

yang dilakukan oleh Hofstein, dkk pada Martinho, Almeida, \& Teixeira-Dias (2014:2537) menyatakan bahawa dengan meningkatkan kemampuan siswa untuk bertanya akan membantu meningkatkan kemampuan kognitif seperti anak mampu menganalisis, berpikir kreatif dan mampu menyelesaikan masalah. Pernyataan tersebut diperkuat oleh Chin \&Brown pada Mueller (2016:42) pembelajaran di kelas yang menggunakan pendekatan anak bertanya dapat meningkatkan pemahaman anak.

Dan Jika dilihat dari N-gain Kelas Kontrol yang rendah maka bisa dilihat bahwa tidak ada perubahan yang signifikan pada penguasaan konsep kelas kontrol. Hal ini menunjukkan bahwa praktik pembelajaran yang masih berpusat pada guru harus segera ditinggalkan karena pada kenyataanya kurang menunjukkan hasil yang maksimal dalam membuat siswa menguasai sebuah materi. Hal ini diperkuat oleh pendapat Mayer pada DeWaelsche (2015:135) menyatakan pembelajaran bermakna terjadi ketika siswa membangun pengetahuannya sendiri dan proses kognitif dibutuhkan untuk penyelesaian masalah, dimana pengetahuan dan proses kognitif ini dibangun bukan dari tranfer pengetahuan dari guru ke siswa tetapi siswa belajar dengan aktif untuk mencari pengetahuannya. Maka dari pernyataanpernyataan di atas dapat disimpulkan bahwa pembelajaran yang masih berpusat pada guru bukan pilihan baik dalam meningkatkan kualitas anak ini terbukti dari hasil analisis profil indikator dan tingkatan taksonomi bloom siswa yang mendapatkan pengajaran tersebut menunjukkan hasil yang positif dalam meningkatkan penguasaan konsep dan jika hal ini biarkan maka akan berpengaruh pada penguasaan konsep pada tingkatan selanjutnya seperti pada penelitian Saat (2012:416) menyatakan bahwa tingkat pemahaman yang dimiliki siswa dari sekolah dasar ke tingkat SMP menunjukkan progres yang minimal salah satu alasannya hal ini dimungkinkan karena kurangnya tingkat pemahaman siswa pada saat sekolah dasar.

\section{SIMPULAN}

Berdasarkan hasil analisis dan pembahasan pada penelitian ini dapat ditarik beberapa kesimpulan yaitu Penggunaan Pendekatan QFT dapat meningkatkan kemampuan siswa untuk bertanya ditunjukkan dari hasil analisis data pada kelas eksperimen jumlah pertanyaan yang dibuat siswa jauh lebih banyak dibanding dengan kelas kontrol, Pertanyaan yang dibuat siswa pada kelas eksperimen lebih banyak pada level LOTS dan belum mampu membuat pertanyaaan pada level HOTS. Hal ini bisa disebabkan oleh berbagai hal salah satunya dikarenakan pengetahuan awal yang dimiliki siswa masih kurang sehinga menjadikan tahapan untuk berpikir tingkat tinggi pun kurang atau bisa juga Qfocus yang dibuat kurang bisa memancing siswa untuk membuat pertanyaan pada level HOTS, dan Peningkatan Penguasaan Konsep IPA pada penelitian ini menunjukkan peningkatan yang signifikan antara kelas eksperimen dan kelas kontrol dimana rerata $\mathrm{N}$-gain sebesar 0,435 .

\section{REKOMENDASI}

Rekomendasi dari penelitian ini adalah dengan lebih banyak menggunakan pendekatan question formulation technique (QFT) dalam pembelajaran, karenaa terbukti dapat meningkatkan kemampan siswa dalam 
bertanya. Untuk dapat membuat siswa dapat bertanya pada level HTOS, diharapkan siswa terus dilatik untuk berpikir ke tingkatan yang lebih tinggi atau dengan membuat Qfokus yang lebih baik agar dapat merangsang pertanyaan.

\section{DAFTAR RUJUKAN}

Badan Standar Nasional Pendidikan. (2005). Peraturan Pemerintah Nomor 19 Tahun 2005 tentang Standar Nasional Pendidikan. Jakarta: Depdiknas.

Badan Standar Nasional Pendidikan. (2006). Peraturan Menteri Pendidikan Nasional Republik Indonesia Nomor 22 Tahun 2006 Tentang Standar Isi Untuk Satuan Pendidikan Dasar Dan Menengah. Jakarta: Depdiknas.

Cardoso, M. J., \& Almeida, P. A. (2014). Fostering Student Questioning in the Study of Photossyntesis. Procedia - Social and Behavioral Sciences, 116, 3776-3780.

Cholifah, S., Hendri, W., \& Deswati, L. (2013). Analisis Faktor-Faktor Penyebab Kesulitan Siswa Dalam Mengungkapkan Pertanyaan Pada Proses Pembelajaran Biologi Kelas Vii. E Jurnal Bung Hatta, 2(4), $1-12$.

Depdiknas. (2003). Undang-Undang No. 20 Tahun 2003 tentang Sistem Pendidikan Nasional. Jakarta: Depdiknas.

DeWaelsche, S. (2015). Critical Thinking, Questioning And Student Engagement In Korean University English Courses. Linguistics and Education, 32, 131-147.

Elves, D. (2013). Questioning Student Questioning: Helping Primary Students Begin To Take More Responsibility Within The Inquiry Cycle (Independent, Small Group And Whole Class Inquiry. Vancouver Island University.

Etemadzadeh, A., Seifi, S., \& Far, H. (2013). The Role Of Questioning Technique In Developing Thinking Skills: The Ongoing Effect On Writing Skill. Procedia-Social and Behavioral, 70, 1024-1031.

Farmer, L. S. . (2014). What is a Question? IFLA Journal, 33(1), 41-49.

Fraenkel, J. R., \& Wallen, N. E. (2013). How to design and evaluate research in education (6th ed.). New York: McGraw-Hill.

Hung, P., Hwang, G., Lee, Y., Wu, T., \& Vogel, B. (2014). A problem-based ubiquitous learning approach to improving the questioning abilities of elementary school students. Educational Technology \& Society, $17(4), 316-334$.

Kemdikbud. (2014). Materi pelatihan implementasi kurikulum. Jakarta: Kemdikbud.

Martinho, M., Almeida, P., \& Teixeira-Dias, J. (2014). Fostering students questioning through Moodle: does it work? Procedia-Social and Behavioral, 116, 2537-2542.

Mueller, R. G. . (2016). Making the fit : exming teacher support for student questioning. Social Studies Research and Practice, , 11(1), 40-55.

Musingafi, M. C., \& Muranda, K. E. (2014). Student and questioning: a review of the role played by students generated question in teaching and learning process. Studies in Social Science and Humanities, , 1(3), $101-1007$.

Patrícia Albergaria Almeida, M. J. C. (2013). Promoting Student Questioning In The Learning Of Natural Sciences. Procedia Social And Behavioral Science, 116, 3781-3785.

Saat, R. (2012). Progression or regression? Children's understanding of the heat concept from primary to secondary school. Procedia-Social and Behavioral Sciences, 9, 414-417.

Siew, N., \& Abdullah, S. (2013). The Impact Of Elstgeest And Alfke’s Questioning Model With Manipulatives On Physics Student Teachers'ability To Generate. Problems of Education in the 21st Century, 54, 99-111.

Şimşek, P., \& Kabapınar, F. (2014). The effects of inquiry-based learning on elementary students' conceptual understanding of matter, scientific process skills and science attitudes. Procedia-Social and Behavioral Sciences, 2, 1190-1194.

Sriarunrasmee, J., \& Suwannatthachote, P. (2015). Virtual Field Trips with Inquiry learning and Critical Thinking Process: A Learning Model to Enhance Students' Science Learning Outcomes. Procedia-Social and, $197,1721-1726$. 
The Right Question Institute. (n.d.). Experiencing the question formulation technique. - Google Search.

Vianata, H. (2012). Pengaruh Model Pembelajaran Question Student Have Terhadap Hasil Belajar IPS Sejarah Siswa. Indonesian Journal of History Education, 1(1), 1-5.

Widodo, P. (2012). Meningkatkan Motivasi Siswa Bertanya melalui Metode Snowball-throwing dalam Pelajaran Pendidikan Kewarganegaraan. Jurnal Pendidikan Penabur, 13(8), 42-55. 